\title{
Fra Grgo Martić kao posrednik između Katoličke Crkve i osmanlijske vlasti u neobjavljenim ljetopisima Franjevačkoga samostana Kreševo
}

MILO JUKIĆ

Kreševo

E-pošta:milo.malum@gmail.com
UDK: 272-789.32/.33(497.6 Kreševo)

94(497.6)

929 Martić G.

Izvorni znanstveni rad

Primljeno: 23. listopada 2019.

Prihvaćeno: 10. lipnja 2020

Sažetak

Gotovo čitavo 19. stoljeće u Bosni i Hercegovini, sve do uspostave austrougarske vlasti, obiluje turbulencijama izazvanim slabljenjem Osmanskoga Carstva i težnjama onodobnih europskih sila da, koliko je to moguće, riješe probleme izazvane takvim stanjem i zbivanjima. Porta na razne načine, ponajprije zakonskim uredbama (Hatišerif od Gülhane 1839., Hatihumajun 1856.) pokušava riješiti probleme, ali nedostaje volje i snage za njihovu provedbu pa su rezultati gotovo neznatni, a položaj katolika i Katoličke Crkve sve je nezavidniji.

Fra Grgo Martić je, kao agent Franjevačke provincije Bosne Srebrene u Sarajevu, više puta bio posrednikom između osmanskih vlasti i Franjevačkoga samostana Kreševo.

* Rad je prezentiran u okviru simpozija "Andrićev Omerpaša Latas" (Bukurešt, 12.-14. listopada 2017.). 
Milo Jukić - Fra Grgo Martić kao posrednik...

U djelovanju na tom planu intenzivno, kao član sarajevskoga Medžlisa (Vijeća), ali i privatno, u granicama mogućega i dopuštenoga, komunicira s predstavnicima vlasti, a za pomoć u rješavanju pojedinih sporova obraća se i diplomatskim predstavnicima drugih država koji su u određenim situacijama mogli ostvariti određeni utjecaj.

Takvi slučajevi detaljno su opisani u neobjavljenim samostanskim ljetopisima vođenim između 1864. i 1878. godine.

Ključne riječi: fra Grgo Martić; Franjevački samostan Kreševo; ljetopisi; vezir; Sarajevo.

\section{Uvod}

Poznato je da su bosanski franjevci 1856. godine, po uzoru na Agenciju u Carigradu, u Sarajevu službeno utemeljili Agenciju, koja je u sljedećem razdoblju, sve do uspostave austrougarske vlasti, zastupala interese bosanskih franjevaca i njihovih samostana kod bosanskih namjesnika (vezira).

Iako bi se pod pojmom "agencija" mogao podrazumijevati čitav jedan administrativni aparat, u stvarnosti je sarajevsku franjevačku agenciju činio jedan čovjek, fra Grgo Martić. ${ }^{1}$ Agencija je djelovala u sarajevskoj četvrti Latinluk, nastanjenoj uglavnom katolicima, gdje se nalazila i katolička crkvica svetog Ante. Na koricama zapisnika navedeno je da je to "Agencija Redovničke Države i Naroda katoličkog u Bosni kod Carsko-osmanske Praviteljstvene Vlasti u Sarajevu pod pervim zastupničtvom Fra Grge Martića Privremenog Agenta".2 Fra Grgo je za agenta izabran između četvorice kandidata, a službeno se smatra da je Agencija utemeljena na inicijativu tadašnjega austrijskoga konzula dr. Dimitrija Atanackovića, ${ }^{3}$ iako se ideja o takvu

1 Opširnije o fra Grginu radu u Agenciji u: Hajrudin Ćurić, Zapisnik Agencije bosanskih franjevaca u Sarajevu, Prilozi bosansko-hercegovačkoj istoriji XIX vijeka, Naučno društvo SR BiH, Sarajevo, 1960.

2 Augustin Čıčić, Monografija o fra Grgi Martiću, Tisak Narodne prosvjete, Zagreb, 1930., str. 13. O radu Agencije: Isto, str. 35.

3 Julijan Jelenić, Kultura i bosanski franjevci, I., Svjetlost, Sarajevo, 1990., str. 286-288. 
čemu spominje mnogo prije, a najkonkretnije 1853. godine u pismu fra Lovre Karaule tadašnjem provincijalu fra Andriji Kujundžiću. ${ }^{4}$

Najveći dio ovdje izložene građe potječe iz ljetopisa kreševskoga samostana. Iako je svaki franjevački samostan dužan voditi vlastitu kroniku (ljetopis), to u kreševskom samostanu tijekom nekoliko desetljeća 19. stoljeća iz nekog razloga nije rađeno. Prethodni ljetopis završava s 1827. godinom, a nanovo je započet tek 1873. godine, i to po fra Dominu Toliću, koji je dužnost ljetopisca obavljao do 1876. godine. Ljetopis potom, do veljače 1879. godine, nastavlja fra Stjepo Momčinović, nakon čega ga piše fra Danijel Ban. Prazninu u dobroj mjeri nadomješta ljetopis koji je od 1864. do 1888. godine privatno vodio fra Anđeo Šunjić. ${ }^{5}$

Službeni samostanski ljetopis paginiran je, a Šunjićev nije, pa ćemo se u bilješkama izvedenim iz njega referirati na mjesece i/li godine kako ih je on označavao.

Sigurno bi se našlo više građe da fra Grgo, plašeći se premetačine i odmazde osmanske vlasti, nije običavao uništavati pisma ${ }^{6}$ Mnoga koja je slao sačuvana su i pronađena u ostavštini primatelja, ${ }^{7}$ ali je mnogo manje onih koja je primio od drugih.

\section{Fra Grgine veze i utjecaji}

Fra Grgo Martić bio je član sarajevskoga Medžlisa (Gradskoga vijeća), i to veoma aktivan, od nemuslimana svakako najaktivniji, a kao takav zastupao je ne samo katolike nego i sve druge kojima je to bilo

4 Pisma bosanskih franjevaca (priredio Željko Ivanković), Synopsis, Sarajevo Zagreb, 2015., str. 225.

5 Službeni samostanski kroničar donosi i događanja u svezi s iznenadnim razbolijevanjem fra Anđela Šunjića. Dogodilo se to u travnju 1874., dok je fra Anđeo bio župnik u Podhumu (Neretva), a tada je izabran za novoga kreševskoga gvardijana. U Konjicu mu se, međutim, prije nego je stupio na novu dužnost, dogodilo da "ga snadje nesreća i poludi", pa je iz Konjica, uz pratnju zaptija, doveden u kreševski samostan. Takvo što mu se, navodi ljetopisac, već događalo, i to dvaput, dok je u Đakovu studirao filozofiju te nešto kasnije, dok je u Italiji studirao bogosloviju. Vodili su ga raznim liječnicima, ali ništa nije urodilo plodom, da bi do ozdravljenja ipak došlo u studenom iste godine. Ljetopis Franjevačkog samostana Kreševo, 3, Arhiv Franjevačkoga samostana Kreševo, kutija 34, oznaka Ljet. 3, str. 87-88.

6 A. Čıčić, nav. dj., str. 14.

7 Pisma bosanskih franjevaca. 
potrebno, o čemu je u literaturi već dovoljno rečeno. ${ }^{8}$ Iako su mnogi, zbog stalne težnje Osman Topal-paše ${ }^{9}$ da sve bude po njegovu, članove Medžlisa nazivali "evetašima" ( $\mathrm{tj}$. onima koji samo potvrđuju, bez stvarnoga utjecaja), ${ }^{10}$ fra Grgo je itekako imao utjecaja na pojedine događaje i znao ga je iskoristiti.

Osim utjecaja koji je imao kao član Medžlisa, fra Grgo nesumnjivo koristi i svoj ugled, a imao ga je ne samo među narodom i osmanskim dužnosnicima, nego i kod stranih diplomatskih predstavnika, koje često dovodi u Kreševo. Tako ljetopisac navodi kako fra Grgo 19. lipnja 1875. u samostan dolazi s austrijskim generalnim konzulom Teodorovićem, ${ }^{11}$ a s njima je "njeki Bečanjin prezimenom Hunbert, koji sad stanuje u Rimu, kog Theodorović naziva Civilnim Papinim Kardinalom, a to valjda iz njege mržnje pram spomenutom Gospodinu i Papi, buduć on Katolik a Theodorović Srbin. Kažu onjem da je proputovao cielu Francuzku Kinu i Europu, i da je velik diplomatik, zbog koji je poslova po Bosni hodo jest nepoznato"..12 Godinu dana kasnije (25. srpnja 1876.) fra Grgo dolazi "...s' gospo. Jozipom Valdhartom Konzulom u Adrianopolu; koga Bečka vlada jest poslala da nagovori fratre i Catolike da Instancim pošalju na Cara radi posjednutja Bosnae..."13 Fra Grgo je u samostanu, jer je imao zdravstvenih problema, ostao tri tjedna. I sljedeće godine, 22. listopada, "jest dolazio fra Grgo Martić iz Sarajeva s' Konzulom Franceskim, te su išli u Visočicu u lov, a 24 (misli se na datum, 24. listopada, op. aut.) već su otišli na-

8 Opširnije u: SRećкo M. DžAJA, "Politički profil fra Grge Martića", u: Bosna franciscana, 4, Sarajevo, 1995., str. 57.

9 Osman Topal-paša vladao je od 1860. do 1869. godine. Opširnije o njemu u: A. Čıčić, nav. dj., str. 38-41. Evo kako ga vidi fra Anđeo Šunjić: "...sad ti P. Štioče promisli kakav taj čovik Osman Šerif Paša mora biti, jaću ti kazati jednom ričju, kesedžija, izjelica, gulioc, nie mu dosta bilo, da mu se dadne sva hazna Careva, uviek mu je malo bilo, i sve mu je vrag nosio, u tudjemu nejma blagosova." Kronoložke bilješke o. fra Angjela Šunjića od g. 1864.-1888., Godina Gospodinova 1869., Arhiv Franjevačkoga samostana Kreševo, kutija 34, oznaka Ljet. 4.

10 J. JELENić, nav. dj., str. 220.

11 Vrlo vjerojatno je fra Grgo imao utjecaja i na činjenicu da je konzul Teodorović, odnosno austrijski konzulat, izdvajao velika financijska sredstva za katoličke škole u Bosni. O toj temi vidi: Jako BALTić, Godišnjak od događaja $i$ promine vrimena u Bosni 1754-1882., Synopsis, Sarajevo - Zagreb, 2003., str. 392-393.

12 Ljetopis Franjevačkog samostana Kreševo, 3, str. 94.

13 Isto, str. 115. 
trag u Sarajevo."14 Također su dobro poznate njegove veze s đakovačkim biskupom Strossmayerom, koji je svoj utjecaj itekako koristio i za ostvarivanje vlastitih političkih ciljeva. Fra Grgo se nije libio moliti za pomoć ni druge velikodostojnike, kako crkvene, tako i svjetovne, što se najbolje vidi po akciji koju je poduzeo 1865. godine s ciljem izgradnje škole u Sarajevu, kada je molbenice poslao mnogima, od sultana Abdul-Aziza pa do talijanskoga kralja Vittoria Emanuela II. ${ }^{15}$

U svim tim aktivnostima fra Grgo je znao odrediti pravu mjeru, što $\mathrm{u}$ ono doba nije bilo nimalo lako, s obzirom na stalnu sumnjičavost osmanskih vlasti, pa i imajući u vidu iskustvo sudbine kolege mu fra Ivana Franje Jukića. ${ }^{16}$ "S pašama piti, a za raju raditi, prijateljevati s konsulima velikih vlasti, a ne izgubiti povjerenje carskih vezira, to bijaše velika i teška rabota", piše fra Grgin suvremenik Kerubin Šegvić. ${ }^{17}$ Ako je morao biti poslušan prema osmanskoj vlasti, imao se pravo, makar više potajno i u sebi, odnosno u granicama dopuštenoga, nadati svekolikoj pomoći zapadnih sila kršćanskom puku u Bosni, pa je tako i nastupao, ${ }^{18}$ a motivi mu nisu usko nacionalni i vjerski, odnosno katolički, nego su, kako Oton Knezović kaže u prikazu njegova pjesničkog rada, usmjereni na jedinstven narodni cilj: "...da (narod) spasi goli život i da izvojuje slobodu". ${ }^{19}$

Svakako treba spomenuti i podatak da se fra Grgo nije pridružio ostalim hercegovačkim franjevcima koji su 1844. godine napustili kreševski samostan i otišli u Hercegovinu, na Čerigaj kod Širokoga Brijega, ${ }^{20}$ što je dovelo do toga da je, kako je, uz bilješku o smrti

14 Isto, str. 133.

15 A. ČIČIĆ, nav. dj., str. 62.

16 O tome u: Tugomir Alaupović, "Ivan Frano Jukić (1818-1857)", u: Biografije bosanskih franjevaca, Synopsis, Sarajevo - Zagreb, 2015., str. 231-338.

17 Kerubin ŠEgvić, "Život i djela fra Grge Martića", u: Ljetopis JAZU za god. 1907., sv. 22, Zagreb, 1908., str. 86.

18 Marko Karamatić, "Duhovni lik fra Grge Martića", u: Bosna franciscana, 4, Sarajevo, 1995., str. 72.

19 Отом Knezović, "Fra Grgo Martić", u: Biografije bosanskih franjevaca, Synopsis, Sarajevo - Zagreb, 2015., str. 631.

20 Zna se da je bilo pokušaja da se Martićeva odluka da ne ode u Hercegovinu promijeni. Usp. pismo fra Ante Vladića upućeno iz Guče Gore 17. kolovoza 1862. fra Grgi na Ponijevo: "U mnogoj mojoj egleni s kustodom Kraljevićem u Rimu, među ostalim reče mi, da će Tebe pozvat u ondašnju Kustodiu da se inkorporiraš i da Te svi onamo žele." Pisma bosanskih franjevaca, str. 557. 
Milo Jukić - Fra Grgo Martić kao posrednik...

fra Andrije Kujundžića naknadno dopisao dr. fra Danijel Ban, "ostao skoro pust ovaj samostan u svom osoblju, jer uz gvardijana Kraljevića i druge oce odselio i novicijat mladeži sa meštrom. Ostalo samo nekoliko rođenih Hercegovaca. Dašto, da je taj odlazak u svakom pogledu prijetio propašću za ovaj samostan..."21 O razlozima zbog kojih je fra Grgo odlučio ostati u Bosni nema pouzdanih podataka.

\section{Fra Grgo kao posrednik između vlasti i kreševskoga samostana}

Loša komunikacija između vlasti i naroda, kako kršćanskoga i hrišćanskoga, tako i muslimanskoga, najbolje se ogleda u sporu oko gradnje zvonika i uporabe zvona ispred kreševskoga samostana.

Izgradnja zvonika pokraj samostanske crkve svete Katarine započela je 1872. godine, "pod upraviteljstvom Velečastnoga Otca fr. Mate Čondrića, za tada Državnika Bosanske Države", a 5. srpnja sljedeće godine stavljen je na vrh zvonika križ "od 15 okah", da bi se osam dana zvono prvi put oglasilo, pozivajući vjernike na pučku Misu ${ }^{22}$ (središnja Misa koja se slavi nedjeljom u 11 sati).

Dozvolu za gradnju dao je, prema ljetopiscu, tadašnji bosanski valija Mustafa Asim-paša ${ }^{23}$ na molbu tadašnjega provincijala Bosne Srebrene, spomenutoga fra Mate Čondrića, inače člana kreševskoga samostana. Mustafa Asim-paša je, uz izdavanje dozvole, naložio fojničkom kajmakamu Ali-agi da ode u Kreševo i "njegovom vlastju priprieči Turcim branjenje zidanja Zvonika". Tijekom Ali-agina boravka u Kreševu tim povodom, u samostanu se, kako kaže ljetopisac, "trefio" i tadašnji austrougarski konzul Svetozar Teodorović, ${ }^{24}$ mada će prije biti da je tu došao s namjerom davanja potpore franjevcima u toj stvari.

Dozvolu da u Kreševu, u samostanu, zazvone zvona dao je još prije toga Topal Šerif Osman-paša, ${ }^{25}$ što je također izazvalo probleme u

21 Ljetopis Franjevačkog samostana Kreševo, 3, str. 73-74. Fra Andrija Kujundžić umro je 27. siječnja 1873. u Kreševu.

22 Isto, str. 75.

23 Mustafa Asim-paša vladao je od 7. studenoga 1872. do 17. studenoga 1873. Fra Anđeo Šunjić tvrdi da je bio "protivnik krstjana". Kronoložke bilješke o. fra Angjela Šunjića od g. 1864.-1888., Godina Gospodinova 1873.

24 Ljetopis Franjevačkog samostana Kreševo, 3, str. 75.

25 Osman Topal-paša vladao od 1860. do 1869. godine. Opširnije o njemu u: A. Čıčıć, nav. dj., str. 38-41. 
odnosima samostana i kreševskih muslimana: "Ja sam uživo dobro povjerenje u Osman Topal-paše, a mazio me od svih drugih ljudi do zazornosti. Zamolim ga u to, da u manastiru Kreševu smijemo zvona dignuti ... Dadne nam to ... protestiraju kreševski Turci protiv zvona ... čuvši to paša, naredi da fratri samo u podne slobodno zvone ... bilo žena u turskoj mahali, koje su za ono vrijeme što se zvonilo, tukle u tepsije da se zvonjenje ne čuje." ${ }^{26}$ Čičić navodi da je dozvolu da zvono zazvoni u Sarajevu, opet fra Grgi kao župniku, na Uskrs 1871. godine dao Hajdar-beg, poslan iz Carigrada da provede reforme u Bosni. ${ }^{27}$

Fra Anđeo Šunjić u svome ljetopisu precizira ${ }^{28}$ da je fra Mato Čondrić pokrenuo inicijativu za izgradnju zvonika zajedno s drugim franjevcima kreševskoga samostana, da su radovi 1872. godine dovedeni "do pola", a dovršeni u proljeće sljedeće godine te da su stajali više od 300 dukata, s tim da je od naroda sakupljeno oko 50 dukata, dok je ostatak novca osigurao samostan.

Kreševski muslimani, pritisnuti valijinom naredbom, dodatno istaknutom Ali-aginim dolaskom, "videći da nije kud, prišute se za neko vrieme, dok se je Zvonik i dogotovio". Međutim, kad se zvono prvi put oglasilo, došlo je do velikih problema: "Ali kada je zvono š njega pobožni puk k službi Božjoj pozvalo, tad na novo od kriu šutnje skupe se i načine Mazar, na Valiju Asim pašu, i pošalju u Banja Luku, gdi se je za tada Vezir bavio vraćajuć bjegunce koji su iz Krajine radi Turskog nasilja pribjegli bili u Austianske Države."29

I o ovome fra Anđeo Šunjić daje podrobniji opis, navodeći da su "Turci Mahaljani"30 žalbu (tijekom kolovoza) uputili na nagovor Salih-age Rezaka iz Fojnice, navodeći "da ne mogu klanjati od zvona". U Banja Luku su žalbu poslali po nekom Salihu Krpi, koji je natrag, u Sarajevo, donio i vezirovu naredbu o zabrani zvonjenja. ${ }^{31}$

Iako je vezir bio najviši organ izvršne vlasti, očito je, barem na neko vrijeme, morao ustuknuti pa je odmah naložio Tahir-paši, svome na-

26 Fra Grgo Martić, Zapamćenja (1829.-1878.), Zagreb, 1906., str. 47.

27 A. Čıčić, nav. dj., str. 42, 54-55.

28 Kronoložke bilješke o. fra Angjela Šunjića od g. 1864.-1888., svibanj 1872.

29 Ljetopis Franjevačkog samostana Kreševo, 3, str. 76.

30 Mahala je dio Kreševa u kojem i danas pretežno žive muslimani.

31 Kronoložke bilješke o. fra Angjela Šunjića od g. 1864.-1888., Godina Gospodinova 1873. 
Milo Jukić - Fra Grgo Martić kao posrednik...

mjesniku u Sarajevu, da obustavi uporabu zvona u Kreševu. Da bi vezirova naredba bila provedena što lakše i bezbolnije, Tahir-paša "koristi" fra Grgu Martića, koji svojim, kreševskim fratrima 31. kolovoza u pisanoj formi objašnjava razloge. ${ }^{32}$

Šunjić, pak, navodi da Tahir-paša nije odmah izvršio vezirovu naredbu "nego kad su mu Turci Mahaljani pokučili dobru svotu novacah, onda zovne P. o. fr. Grgu Martića meldžiza i Većila od sve Bosne te mu rekne: Valia naredjuje da se ono Zvono u Kreševu zastavi, odma ti naredi njima da zastave, ako netili poslušati ja ću poslat Tabor Askera". ${ }^{33}$ Kreševski gvardijan je u to vrijeme bio fra Anto Musić.

\section{Poštovani Otče Guardiane!}

Nenadano i veleneugodno Vam jednu zapovied priobćavam: danas mi naredi Valin namjestnik Tahir Paša po zapoviedi Č. G. Vali Paše, ili da idem tamo ili da pišem da s tog novog zvonika skinete zvona, i prinesete na ono mjesto gdi su prie zvonila, ili zaustavite zvonjenje dok Vam se iz Carigrada dozvoljenje ne dobie. Za dobiti pako potribito zvonjenju dopusćenje isti mi telegrafom G. Thair Paša svojom čestju jamči, ito što prie, samo da ja petitiu učinim. To su Vam dobre Komšie Turci izradili koji su napravili ogromni Mazar i uputili Vali Paši u Banja Luku dokazavši da je ta kula brez dopušćenja i protiv privoljenju hućumetskom načinjena - da je blizu džamie $i$ da oni tude stanovati nemogu i Ezan učiti ako se zvona ne uklone etc. etc. Kazao sam ja Paši da je, s privoljenjem tadašnjeg Vezira koji je poslao Kajmakama Aliagu maksus, $i$ tu da je G. Theodorović $i$ ja isti oni dan bio sagradjenja. Finaliter Valin namjestnik nemogavši drugo, kako više reko, naredjuje a ja nemogavši drugo primi dužnost na se da Vam javim s pouzdanjem da će te toj naredbi sen pokoriti i sustrpljenjem ispravak $i$ službeno dopušćenje za koje ću koliko je sutra inicijativu preduzeti, čekati.

Čim Vam ovo do znanja stavljam ostajem s dužnim štovanjem.

U Sarajevu dn. 30. Kolovoza 1873.

Vaš fra Grgo Martić Župnik

32 Ljetopis Franjevačkog samostana Kreševo, 3, str. 76.

33 Kronoložke bilješke o. fra Angjela Šunjića od g. 1864.-1888., Godina Gospodinova 1873. 
Ljetopisac fra Domin Tolić je, dakako, razočaran događanjima vezanim za izgradnju zvonika i upotrebu zvona i stavlja ih u kontekst netrpeljivosti osmanske vlasti prema kršćanima: "Rat koji je protiv Crkvi Katoličanskoj i njezinim sinovima evo priko 4. Stoljetja trajao, može svak uviditi iz slidećega slučaja, da još nigda nie dokončan." Slično reagira i nakon fra Grgina pisma, ali izražava vjeru da je Božja providnost riješiti problem: "Čim ovo pismo za svu obćinu nepovoljno stigne ončas zvonik bude zabravljen. Eto se vidi od tale, koliko su ljudi neprijatelji vjere Isusove bili protivni jednoj stvari koja jim ni najmanje nije na put stajala. Ali opet divan je Bog u djelih svojih!"34

Zvonjenje je, dakako, odmah obustavljeno, a zvonik zaključan, pa ljetopisac u veljači sljedeće, 1874. godine nastavlja pisati u istom kontekstu, i to s namjerom "da naši potomci znadu, koliko je jadah i nezgoda dotično stariešinstvo imali i pritrpilo, a to sve sbog stvari kojom se Bog fali i slavi, i koja nije ni najmanje zlobnim neprijateljom Križa Isusova naput stajala, niti jih i u čemu priečila". ${ }^{35}$ Sve aktivnosti u svezi s tim obustavljene su, a ljetopisac navodi da se čekao povratak inicijatora gradnje, provincijala fra Mate Čondrića, koji se u vrijeme kad je pismo stiglo u samostan nalazio u Livnu. ${ }^{36}$

Čondrić se, čim se vratio, 15. prosinca 1873., obratio francuskom konzulu Henriku Moreauu, koji se ne jednom zauzeo za bosanske katolike (austrougarski konzul Teodorović nalazio se $\mathrm{u}$ to doba $\mathrm{u}$ Beču). U pismu je potanko opisano sve što se događalo $s$ gradnjom zvonika i korištenjem zvona, kao i opće političke prilike u Osmanskom Carstvu toga doba. ${ }^{37}$

\section{Prisvietli Gospodine Konzule, Gospodine Najmilostiviji!}

Dobro je Vašem Prisvietlom Gospodstvu znano, kako sudbina koja čovjekom vlada, natjera svakoga, i pojedinoga u razne okolnosti, $i$ puno putah tako težke, da ih se čovjek lišit brez, velika napora, i postojanog truda nemože. Opće namienjeni vrhu svakog udes, nemožeh dakako ni ovu Redovničku općinu, niti općinu Katoličkog naroda, u ovomu mjestu i mieru ostaviti, nego s, nami koleba, i drma tako, da si naj-

34 Ljetopis Franjevačkog samostana Kreševo, 3, str. 75.

35 Isto, str. 79.

36 Isto.

37 Isto, str. 80. 
Milo Jukić - Fra Grgo Martić kao posrednik...

čvrstje sredstvo pronaći moremo, i to uloživ svu silu, i snagu, da se ove napasti - inače jur po G. Isusu u otče našu prorečene izbavimo.

Pravi je Bog kao bitje najmožniji u kog naše oči uprte moraju biti jerbo koji je naoblačio, možan je tminu raztersti i raztjerati dotle, doklegod sjajne zrake Božje blagodati, i blestajućeg se sunca ne ukažu. - Drugo je posridovanje dobročiniteljah, koje je Bog za izvest svoju nakanu kao restva dao, da njegovu svetu volju vrše. Kad se je pako ovako vrhu nas Božja providnost izlie, nama s, baba gledišta nastaje nova dužnost, Bogu i Dobročiniocem viek zafalniem biti, i nikad iz moleti ih neostaviti.

Da pak što pria na stvar pridjem, i izrečem ono što me na srcu tišti, jest slideće, Vama će prisvietli G. i to biti vrlo dobro znano, kako je ovaj redovnički samostan, ujedno s doličnom Crkvom prie padnutja Bosne pod jaram Otomanski sagradjen, od koga vremena kadje i najgora bura progonstva bjesnila, vrhu naših glavah tja doskora zvonila su zvona unutra. - Kojim bi se označilo službe Božje vrimena za svako doba. Ali poslie, kad jur visoka Porta na interpelecii Katoličkih, vladarah ravnopravnost, $i$ njegu slobodu proglasi Kršćanom u svom Carstvu, $i$ to nazad desetak godinah, imavših - ovaj isti Samostan formalna zvona došnja, čega radi stariešine ovog Samostana medju zidinam Samostanskim sagradiše nješto Tornjića drvenog zvonili su istijem zvonima, i glasivali njima u bogu narodu vrieme kad će služba Božia započet. Poslie pak uvidiv napomenute stariešine da će viek biti pogibil za drvena i slaba Tornjića zvoniti, žrtvovali su se mah to bilo $i$ $s$, velikim naporom, te su uzdajuć se u Boga, a pomalo i upomoć puka sjeromašnog, odredili štogod Tornja od kamena sazidat uz crkvu na onom miestu, na kom ste ga sami očima vidili.

Poslie velikog napora $i$ žrtve, Toranj prošle godine bih dovršen, i zvona prozvone na istomu Tornju, i zvonila su do mjeseca Kolovoza prošaste godine. Nut mora se znati; da ovdišni mali broj Turakah, čim su saznali da se Toranj hoće praviti, brez ikakva razloga jesu harsahale pronili; da se gradjevina Tornja priprieči. Uslied toga Valia Bosanski jest deputovao Kajmakama Fojničkog, da izvidi, dali kakva zaprika, što se Toranj načinja. Kajmakan došav ovamo na razvidjenje, slučajno u Kreševu najdje i Gospodina Theodorovića Konsula Austro-Ugarskog koji samo onako s, fra Grgom biaše ovamo došao. Kajmakan u prisutnosti rečenog Konzula sve je razmislio, ovdašnje Turke skupio na medžiz, ter jim odprto kazao, da tu nejima nikakve protivnosti što se Toranj gradi; da je Carska u tomu dozvola, i da u takoj golemoj dolini ništa Turcim nesmeta, na dodav da je u pustinji i u šumi. - Nami napokon reče, vi gradite. 
Mismo onda za poso prionuli, i Toranj one godine do mjeseca Srpnja dokončali. - Nut ipak netjeh mirovati mala obćina Turakah ovdi od 30. Kućah, nego nanovo pogriaše tužbu protiva Tornju, da jim je suprot zakonu, i tako dalje, čega radi i harsohal dadoše. Poslie nam nije Kapia ništa in forma spremala, ni zapovidila, no namje fra Grgo pisao list, u kom kaže: da Kapia želi, da se ustave za sad zvona, zbog neprividjenih posledicah koje bise mogle porodit. Mi istina na ovaj privatni list $i$ zahtievanje, mogli smo ista zvona neustavljat; al budući smo u dobroj nadi bili daće što skorie auctoritetično prozvonit, kao što je Kapia i obećala, skroz mjesec danah tvrdo, mismo ustavili da nezvoni. Mi sad očajasmo čekajuć, i poslie drugog a i trećeg, i četvrtoga mjeseca, dalićemo dobit vlast, zvoniti, pak ni danas ništa. Pisalismo skoro na fr. Grgu dali ćenam odkle svanuti? Ali on odgovara: da se u to ime utekao $k$, Vašem Prisvietlom Gospodstvu dabi Vi svojim mogućim uplivom kod Kapie posredovali, i vlast da možemo zvoniti izposlovali.

Na pokon nam javlja fr. Grgo, daste u tu svrhu jurve kod prošloga Valie blagoizvolili, korak učiniti; al buduć da se Valia promieni, odkle već $i$ stvar se prekide.

Opet kaže fr. Grgo da Vas je molio, da i kod ovog Valije proslidite našu molbu; zaoto i ja Vas najpokornije umoljavam, da se Vaša, dobrota, vruće zauzme nebil već ovih dnevah Božićnih oglasila se zvona, inače nepravedno obustavljena, da čim svi narodi krstjanski s, uzitjenjenjem nastajuće dneve božićne kane proslaviti, i naša ova drugačie najveća u Bosni Katolička obćina, sa svojim sveštenstvom obraduje se. I dosad smo viek suncem griani bili od Francuzkog slavnog Konzula, i naše su prošnje uslišavane bile. -

Možete milostivo Vas položaj ovog mjesta protomačiti, jer ga dobro poznajete, dokazat da smo u šumi odalečeni od Turakah na četvrt sahata, i naša da je Crkva fermanile sagradjena, iz nova s' Fermanom načinjena, uz Crkvu pako nerazdruženo Toranj ul valja da stoji, najposlin, da se je to i po drugim mjestima oživotvorilo i.t.d.

Ovu milost proseći, s, velikom nadom i ufanjem na službu viek priprav, $i$ vazda pokoran i zafalan ostajem.

U Kreševu 15. prosinca 1873.

Fr. Mato Čondrić Državnik 
Novi valija, Arnaud Mehmed Akif-paša, ${ }^{38}$ postavio je stvari drugačije od svoga prethodnika: poslao je po muslimane, vođe pobune, svoga juzbašu koji ih je odveo ${ }^{39}$ na saslušanje u Sarajevo. Tamo su ostali 5-6 dana i, izgleda, odustali od dotadašnjih stajališta, jer je 3. veljače 1874. iz Sarajeva stigao u samostan neki Pero Sahadžija, ${ }^{40}$ "poslat od Vezirove Kapie", a sljedećega dana u Kreševu je postavljen novi mudir, Mehmed-aga, ${ }^{41}$ koji je donio i vezirovo dopuštenje da se zvono ipak može koristiti.

Fra Anđeo Šunjić navodi da konzul Moreau "odma javi vladi francuzkoj cielu stvar, kako Turska Vlada neobslužuje Atihmajuma, ${ }^{42}$ kako u Bosni Krstjani nemaju slobode vierske, kad je sve ono razumila Vlada Francuzka, odma je brzojavom (Telegrafom) javila u Carigrad Vladi Turskoj, kako je ona prikršila ugovor od god. 1856. sbog slobode vierske, Turska Vlada u Carigradu za tu stvar nie znala, nego

38 Arnaut Mehmed Akif-paša vladao je od 28. studenoga 1873. do 6. travnja 1874., nakon čega je premješten u Carigrad, u ondašnju vladu. Ljetopisac ne štedi u pohvalama Akif paši: "Ovaj je bio tako vješt vladalac i svakom brez razlike vjere i zakon pravedan, da se može onjem kazat da je zlata vriedio. Kolikom je na mlogo mjestah dozvolio pravedna njihovah zahtijevanja, njegovom zapoviedju su u Kreševu zabranita zvona prozvonila, osobito je nastojao da se zloporabe činovničtva izkoriene, i da se valjane uprave u sudovim preustroje, a toga smo najviše u Bosni trebali, više nego i ukojoj zemlji svieta." Isto, str. 84. Naslijedit će ga Derviš-paša, "poznat iz g. 1863. iz bitke Crnogorske", a tijekom njegova mandata izbit će Hercegovački ustanak (1875.-1878.). I fra Anđeo Šunjić odmah po stupanju Akif-paše na dužnost iznosi mišljenje kako mu se čini "da će dobar biti po Krstjane". Kronoložke bilješke o. fra Angjela Šunjića od g. 1864.-1888., Godina Gospodinova 1873.

39 Prema fra Anđelovom ljetopisu odvedeno ih je "do 30". Isto, Godina Gospodinova 1873.

40 U originalu Pero Sahačia. Ljetopis Franjevačkog samostana Kreševo, 3, str. 82. Prema fra Anđelovu ljetopisu, riječ je o Pavi Sičaji. Kronoložke bilješke o. fra Angjela Šunjića od g. 1864.-1888., Godina Gospodinova 1873.

41 Mehmed Aga je na službi u Kreševu ostao do ranoga proljeća 1874., a zamijenio ga je neki Bećir-aga iz Travnika. Ljetopisac i njega opisuje pozitivno: "Glede spomenutoga gori Mehmed Age, ima se to kazat, da je on bio vrlo privržen Fratrima ovoga Samostana, indi trebalogaje svakog kakva slučaja i glede ovog samostana zamoliti, a i glede Krstjana, a to bi on na molbu samostanskoga Ravnateljstva bio sklon. Stoga nie bio fratrim nikako povoljan njegov odlazak, prem je bio i glede, Krstjana i Turakah vrlo strog te je više puta biuć na očitovanje prekršaja nateravao." Ljetopis Franjevačkog samostana Kreševo, 3, str. 84.

42 Hatihumajun, sultanov ukaz iz 1856. godine kojim se prava nemuslimanskog stanovništva u Osmanskom Carstvu izjednačavaju s pravima muslimana. 
Valia Bosanski to je uradio podmićen novcim od Turaka Kreševski, od Vlade Turske iz Carigrada po brzojavu dodje u Sarajevo Valii masna popara porad Zvona, t.j. da se odma naredi fratrim u Kreševu da odsele slobodno zvone." ${ }^{143}$

Mora da je u svemu bilo i likovanja katolika na takvu odluku, čim fra Anđeo navodi kako je "zvono zvonilo od jutra do posli podne na 1. sath". Dogodilo se to 8 . veljače $1874 .{ }^{44}$

Ljetopisac na kraju svega najveće zasluge što je zvono ponovo moglo zvoniti daje konzulu Henriku Moreauu i fra Grgi Martiću koji "jesu se svojski zauzeli kod Gospodina Vali Paše te gori spomenutu stvar izposlovali". 45

Fra Grgo posreduje i u slučaju ${ }^{46}$ koji se dogodio noću 20. siječnja 1870., kada su lepeničkoga ${ }^{47}$ kapelana fra Marka Vilića, koji je sa slugom pošao u obližnji Ljetovik, podijeliti bolesničko pomazanje, na Brnjacima napali Muhamed Zildžić i Arif Zehorović. Dvojicu su razbojnika uhvatili mještani na čelu s knezom Antunom Buzukom, koje je uzbunio fra Markov sluga, i doveli ih u Omeragića han, gdje je nešto kasnije stigao i fra Marko. Kako ih nisu smjeli vezati ni razoružati, Zildžić iskoristi priliku i ponovo napadne fra Marka, slomivši mu vlastitu pušku o glavu, na što skoči vlasnik hana Omeragić i zajedno s mještanima razoruža Zildžića. Odmah je kadiji predana tužba protiv dvojice razbojnika, koji su iste noći ipak pušteni, a o svemu je upoznat i fra Grgo, kako bi intervenirao kod vezira. Fra Grgo je uspio ishoditi da u Lepenicu dođe liječnik koji je pregledao fra Marka, dok je osam kavaza ${ }^{48}$ prispjelih iz Sarajeva uhitilo Zildžića te organiziralo potragu za Zehorovićem.

Franjevci su ostali u čudu kad ih je fra Grgo 29. siječnja pozvao u Sarajevo: doznali su da je Zildžićev otac podnio tužbu "...da je fratar (tj. fra Marko) sa 100. Vlaha udario na han, te oteo dvie puške srmali,

43 Kronoložke bilješke o. fra Angjela Šunjića od g. 1864.-1888., Godina Gospodinova 1873.

44 Isto.

45 Ljetopis Franjevačkog samostana Kreševo, 3, str. 82-83.

46 Kronoložke bilješke o. fra Angjela Šunjića od g. 1864.-1888., Siečanj m. 1870.

47 Lepenica je selo i župa u općini Kiseljak (zahvaća i dio općine Kreševo) koji pripada kreševskom samostanu.

48 Policijski službenik višega ranga. 
nož veliki, i kesu od novacah mirinski oko 7. Kesah, to čini 3500. Gr. i da drže njegova sina Muhameda u hapstu bigarijak, t.j. nepravedno, da nie kriv ništa ko što su rekli na njega". Na sudu se, dakako, ispostavilo da je sve bilo drugačije te da je Zildžić opljačkao fra Marka, što je i priznao, obećavši da će štetu nadoknaditi, pa je na to obećanje pušten. Šteta, dakako, nikad nije nadoknađena, iako se fra Grgo više puta susretao sa Zildžićevim ocem, koji je svaki put rekao kako će platiti dug, ali je na kraju sve bilo uzalud.

U svjetlu općih političkih, ekonomskih i socijalnih prilika ${ }^{49}$ koje su prethodile Hercegovačkom ustanku (1875.-1878.), kreševski franjevci obavljaju i brojne druge aktivnosti izvan ustaljenih redovničkih, pa su u ožujku 1874., uz pomoć društva "Immaculatae Conceptionis Beate Mariae Virginis" iz Beča nabavili prve orgulje, ${ }^{50}$ a prije toga su, 3. svibnja 1873., u samostanskom dvorištu postavili temeljni kamen za novu školsku zgradu, koju su završili 2. rujna iste godine. ${ }^{51}$

Unatoč sasvim izvjesnoj spremnosti tadašnjih vezira i njihovih najbližih suradnika za rješavanje problema katolika, makar ono možda bilo parcijalno, od slučaja do slučaja, domaći muslimani, uključujući i neke od nižih činovnika, nerijetko se ne žele uklopiti u takva gledanja.

49 Ljetopisac te (ne)prilike potanko opisuje u rezimeu 1873. godine: "Premda smo, mloga plačna i gorka počimau od vrimena osvojenja Kraljestva Bosanskog, pak do danas, zbog različitih uzrokah, osobito vjerski pritrpili, nu natoliko je ovih godinah poslidnjih, težina i velikoća nevoljah, naraslo, na ime od nesnosnog jarma Turskog da nas sva težina i velikoća, nemal nije sasvim pritiskla, što bi bilo da nas nije Providnost Božija učuvala; dapače sad je stvar nato došla, da smrt ista bilabi nam sladja, nego život, s tolikim nevoljama obasut, tako da, dignuvši oči k, nebu često smo putah bili usilovani zaviknuti one rieči svetog pisma 'Melius est nos mori quam videre mala sanctorum' (Machab 3.59.). Proljetje ove godine bilo je težko za biedni narod glada i patnje je bilo primlogo, jerbo je žito bilo skupo tako, daje cejrek ječma prodavaose po 46, - 41 do 48 . Nu jesen je donila prilični ljetni plod žitoje rodilo osridnje kao Kukuruzi, ječam, Proja, a šenica, sasvim slabo, buduć za rana Tljavom ubjena. Što se pako tiče voća, ovda posliedi Bosne nie baš ni za izjest bilo, akamoli se na drugi način š, njim okoristiti, osim Neretve i Posavine, u kojoj su šljive bile prilično rodile. Po dješto se je i bolesti uz ovu godinu (Kolere) pojavljivalo, kao po Kraini, osobito oko Banje-Luke, oko Turskog Broda, Dervente, nu dalje se spomenuta bolest nije pružala". Ljetopis Franjevačkog samostana Kreševo, 3, str. 77. U srpnju i rujnu 1874. godine zavladala je, pak, epidemija crnog prišta koji je "mnoge ne štedeći nit cieneć, ni mladost ni ljepotu u hladni grob strovalio." Isto, str. 87.

50 Isto, str. 84-85.

51 Isto, str. 75. 
To dobro ilustrira i slučaj ${ }^{52}$ koji se dogodio u siječnju 1874 . Tada je konjički kajmakam Ibrahim-beg Stambolija po nalogu Vali-paše javno oglasio da se prodaje samostanski posjed u konjičkom selu Mrakovi. Samostan je imanje pedesetak godina prije kupio od nekog Adžije Gigovića iz Sarajeva, a osmanska vlast uporište je pronašla u tome što imanje nije prevedeno na samostan nego na pojedine franjevce (fra Andrija Kujundžić, fra Filip Letić, fra Ilija Skoko i fra Andrija Karačić). Kako su oni pomrli, vlast je smatrala da imanje više ne pripada samostanu.

Fra Anđeo Šunjić detaljno opisuje likovanje konjičkih muslimana: "... da ti je bilo vidjeti turke po Konjicu kako su činili veselje po Kavam što se telali po Varoši Čifluk fratarski, oni su govorili medju sobom pade Krst, nejma ništa od Krsta, kamo jim sada Francuz, Niemac, i Mozgov, neka zabrane da jim se neprodade Čifluk u Mrakovu, naš je Car Sultan Abdul Asiz jači od sviju njihovi Kralja, naša je vjera jača od njihova Krsta, i još tomu slično govorilisu medju sobom u Varošim, i po selim..." ${ }^{53}$

Uzrok svemu bila je ljutnja nekog Avde Ćosića iz Šabančića na samostanskoga kmeta Ivana Božića, a Ćosićev naum da razvlasti franjevce svesrdno su podržali nekadašnji zakupnici imanja Zulfo Alagić ("... zakupnik desetina Carski Zulfo Alagić od stari pasah okrnjak..."), Junus Proha i Husein Komadina, koji su se odmah pojavili kao potencijalni kupci, ali, dakako, ne od samostana nego od države.

Predstavnici samostana odmah su se, jer se radilo o velikom i vrijednom imanju, preko provincijala fra Mate Čondrića, obratili "Caru Frani Jozipu, i na Ungarsko Ministarstvo", naglasivši da će, ako se ništa ne učini, "Turci prodavati našu svu zemlju štogod imamo u Bosni, buduć da se misnici nežene, i nejmadu komu ostaviti po turskom zakonu (pasjaku)". Također je pisano i državnim vlastima u Carigradu.

Najviše muke i truda, nastavlja fra Anđeo, imali su fra Grgo Martić i on osobno. Fra Anđeo je u sve bio izravno uključen, jer je imanje u Mrakovu pripadalo župi Podhum, gdje je on tada bio župnikom. Za fra Grgu piše da je "priko njegove glave sve je prišlo, buduć on meldžizom na Kapii Sarajskoj, zato štogod bi Valia hotio narediti Mutesarifu mostarskom porad toga Čifluka, on bi zovnuo Martića,

52 Kronoložke bilješke o. fra Angjela Šunjića od g. 1864.-1888., Siečanj misec. 1874.

53 Isto. 
Milo Jukić - Fra Grgo Martić kao posrednik...

te mu kako je stiglo iz Carigrada kazo, i Martić je jednoč otišo u Mostar porad toga Cifluka...".

Spor je trajao oko dvije godine, samostanski kmetovi (spomenuti Ivan Božić te Marijan Kovačević i Mijo Lozić) otjerani su i u zatvor te tamo prisiljeni da desetinu, umjesto samostanu, dadnu Zulfi Alagiću. Na kraju je sve, uz velike troškove, te ponajviše zahvaljujući fra Grginim aktivnostima, kao i prosvjedima austrijskoga i mađarskoga dvora osmanlijskoj vladi u Carigradu, ipak riješeno povoljno.

Nepovoljno je, pak, završio slučaj ${ }^{54}$ koji se dogodio 8. siječnja 1874., kada je u samostan, dok su fratri ručali, došao Kreševljak Ašim Medranović, "pjan i oružan", kako navodi ljetopisac, koji dalje nastavlja: "...i premda je tude bio podvoren s' jelom, s' kafom, ništa nemanje, buduć počeo psovat 'sve Fratre', neki su se stog uklonili otišav u svoje sobe. - Nu njeki iz medju Častni Otacah ove obštine ostanu u Blagovalištu i dalje za viditi, šta je spomenuti Ašim namislio provest, a on i nadalje psujući, osobito poče prietit Častnom Otcu fr. Petru Tomiću za tada Koristi, na kog reče, da će njegov Garabin puknuti, zatim baciv findžan s, kojim je kafu pio izajde, i uzjašiv svog konja kog je u Pillu na način bašinskih vrimena odjašio kad je došao, ode prošav kraj Glavica, tude pokaže svoje barbarstvo ubiv iz puške naše pašče koje smo mi mlogo cienili, ode u Dusinu."

Samostan je Merdanovića najprije tužio mjesnom sudu u Kreševu, a potom i onom višem, u susjednoj Fojnici. Fojnički kajmakam pismeno je odgovorio samostanu, "obećavši tvrdo, da će se osgori spomenutim Ašimom strogo postupat...". Doista je na fojnički sud već 15. siječnja pozvan spomenuti fra Petar Tomić, koji je u Fojnici proveo tri dana, ali se parnica završi nepovoljno za samostan, jer se za Merdanovića, zbog tko zna kakvih okolnosti, zauzeo fojnički fratar fra Mijo Gujić, koji je našao "dva jamca (ćefila) da će ubuduće mjerovat i da će fratri bit sigurni toli glede svojih dobara, toli glede sebe svakog na posebice".

Merdanović je tako ubrzo pušten iz pritvora bez ikakve osude, iako je probleme franjevcima (a i mnogim drugim) pravio i prije, i to ne jednom. Tako je 1869. godine u Deževicama "zametnuo kavgu" u kojoj je teško pretučen, kao i njegov radnik Pavo Šerkić. Malo potom (5. travnja) on i njegov brat Emin u zasjedi su dočekali i nanijeli teške povrede Jozi Davidoviću, zbog čega su šest dana kasnije, zajedno

54 Ljetopis Franjevačkog samostana Kreševo, 3, str. 78-79. 
s ocem Mehom i trećim bratom Ahmetom, uhićeni i sprovedeni u Sarajevo. Iz pritvora su, preko Kreševljaka Mehe Kambura, tražili od franjevaca da napišu pismo u njihovu obranu, što su ovi odbili. Njihova majka nekoliko dana kasnije poslala im je u posjet četvrtog sina, Avdiju, koji u putu prema Sarajevu opljačka Škembinu kavu (kavanu) te je i on pritvoren. Na kraju je Avdija osuđen na tri mjeseca zatvora, a njegova braća i otac oslobođeni. ${ }^{55}$

Avdija se u ljetopisima ponovo spominje u svibnju 1876., kada je kod Tunješovih mlinova nađen zaklan Ivan Ćusto (Suđerić). Iako je po svemu bilo očito da je Avdija bio izvršitelj ubojstva, u zatvoru u Fojnici ostao je samo mjesec dana, nakon čega je pušten na slobodu. ${ }^{56}$

Dvije godine kasnije Ašim je u Deževicama, ${ }^{57}$ za blagdan Gospe Snježne, opet napravio kavgu u kojoj je teško stradao Stjepan Poljko (Pordušić), kojega su jedva živa "na konju donieli" u Kreševo. Drugoga dana proslave Ašim je zabranio fra Grgi Franićeviću služiti Misu. Zaptije su sljedećega dana pokušali uhititi Ašima, ali je on "nož veliki potego, pak jim reko, tkomu nie žao umrieti neka prifati za me, i tako ostane slobodan". Na kraju su ga uhitili zaptije iz Fojnice, ali je ubrzo pušten, nakon što je, po mišljenju ljetopisca, bogato podmitio kadiju "...te Ašim postane gori pas nego prie. Eto moj P. Štioče pravog suda u Turakah".58

Puno gori slučaj, koji ujedno dodatno ilustrira nespremnost kreševskih muslimana da prihvate odluke više vlasti u pogledu korištenja zvona, dogodio se 15. veljače iste godine. Toga jutra je u Sirišnjaku, između Kreševa i Kotarca (danas dijelu Kreševa), nađen ubijen neki musliman iz Fojnice, zbog čega su zaptije poduzeli veliku akciju i u Kreševo priveli gotovo cjelokupno stanovništvo obližnjih sela koji su "...tude izpitivani, u vast ${ }^{59}$ zatvorani i mlogi bieni od Mehmed Age za tada zabita Kreševskog...". Ispostavilo se, navodi ljetopisac, da je ubojica Pero Čustonjić iz Dusine, na službi u obitelji Gavran, mladić u dobi od 16-17 godina. Čustonjić se na sudu branio ovako: "Ja sam ubio istina onog Turčina ali zato što mi je kad sam ga u noći sreo op-

55 Kronoložke bilješke o. fra Angjela Šunjića od g. 1864.-1888., Godina Gospodinova 1869.

56 Isto, Svibanj misec. 1876.

57 Selo i župa u općini Kreševo (dijelom se proteže i na područje općine Fojnica).

58 Isto, Godina Gospodinova. 1871.

59 Misli se na avs = zatvor. 
Milo Jukić - Fra Grgo Martić kao posrednik...

sovao Krst, i rekao mi još ovdi vlaše zvona ne zvone, i što je štapom zamanuo da me udari udario sam ga dva put kolcem po glavi". ${ }^{60}$ Sve se to događa samo osam dana nakon što se zvono prvi put oglasilo.

Slične događaje koju godinu prije bilježi i fra Anđeo Šunjić (ubojstvo nekog židova u Kreševu, za koje su osumnjičeni kršćani, a ispostavilo se da su ga ubili trojica kreševskih muslimana /1864./, ${ }^{61}$ ubojstvo Ante Sabljića, za koje je, kao i za prethodno, odgovoran bio Ibrahim Merdan /1865./ ${ }^{62}$ nanošenje štete nekom Tunješu iz Polja od kreševskoga mudira Mehmed-age /1869.//, ${ }^{63}$ ubojstvo Kate Milinušić koje je počinio neki "Sarajlija turčin" /1870./ ${ }^{64}$ itd.

Opća nesigurnost dodatno je porasla izbijanjem Hercegovačkoga ustanka (1875.), o čemu ljetopisci sljedeće tri godine, za trajanja ustanka, iako je u Kreševu cijelo vrijeme razmjerno mirno, prilično iscrpno pišu, a navode i slučajeve nasilja vezane za svoju subraću (ubojstvo fra Lovre Karaule kod Livna, ${ }^{65}$ zapaljene crkve u Čukliću i Banjoj Luci, ${ }^{66}$ razbojstvo nad neimenovanim kapelanom iz Busovače,${ }^{67}$ ranjavanje fra Mije Marijanovića u Čukliću ${ }^{68}$ itd.). To je, dakako, tek manji dio napada usmjerenih na franjevce i katolike te njihove crkve. ${ }^{69}$

Iako su, i tad i prije toga, u većini slučajeva počinitelji muslimani, često je vidljivo nastojanje da se izbjegne generaliziranje, a usto se nastoje istaknuti pozitivni primjeri mogućega suživota (primjerice kada se zapalila samostanska štala pa su u gašenju požara sudjelovali i kreševski muslimani ${ }^{70}$ ili kad su franjevci i katolici išli u radnu akciju u Kostajnicu /1876./, a među ostalim sudjelovao je "...i Numo

60 Ljetopis Franjevačkog samostana Kreševo, 3, str. 83.

61 Kronoložke bilješke o. fra Angjela Šunjića od g. 1864.-1888., na 1., nenaslovljenoj stranici.

62 Isto, Godina Gospodinova 1865.

63 Isto, Godina Gospodinova 1869.

64 Isto, Ožujak misec. 1870.

65 Ljetopis Franjevačkog samostana Kreševo, 3, str. 96-97.

66 Isto, str. 118.

67 Isto, str. 126.

68 Isto, str. 127.

69 Opširnije o tome u: J. Jelenić, nav. dj., str. 224.

70 Kronoložke bilješke o. fra Angjela Šunjića od g. 1864.-1888., Godina Gospodinova 1868. 
Muminov iz mahale turske"71 odnosno, kako u svom ljetopisu precizira Šunjić, Numan, sin hodže Muminovića, za koga kaže da "...vrlo se je dobro podnio u poslu i u ponašanju"). ${ }^{72}$ Unatoč činjenici da su se katolici u velikoj mjeri uključili u ustanak, franjevci nastoje održati dobre odnose s predstavnicima osmanske vlasti pa, primjerice, valiji u Sarajevo, uz popratno pismo, šalju divljeg jarca kojega su stanovnici Deževica ubili i darovali fra Stjepi Momčinoviću (ožujak 1877.). ${ }^{73}$

\section{Kreševski fratri o fra Grgi}

Unatoč uvriježenom i sveprisutnom stajalištu o fra Grgi kao pozitivnoj osobi u svemu čega se u svome djelovanju doticao, njegova subraća u Kreševu katkad su iznosila potpuno suprotna mišljenja. To se najbolje vidi u bilješci o njegovoj smrti u službenom samostanskom ljetopisu, gdje se donose ${ }^{74}$ brojni detalji iz pokojnikova životopisa te s pogreba, iz kojih se vidi da je bio iznimno cijenjen. Pogrebu su, uz ostale, prisustvovali izaslanici iz svih bosanskohercegovačkih samostana, iz brojnih kulturnih društava iz BiH i Hrvatske, oba provincijala, kao i okružni predstojnik iz Sarajeva, baron dr. Mollynari, te kotarski predstojnik iz Fojnice dr. Josip Matasović. Ljetopisac na kraju službenoga dijela kaže kako je fra Grgo bio "najnaobraženiji čovjek u ono vrieme u Bosni i Hercegovini što se tiče svjetovnog znanja", ali nastavlja i da "...nu žalibože, kao redovnik i svećenik franjevac nije se ponašo" te da "svjetovnjaci su ga hvalili i slavili, nu u franjevačkom redu nije bio na dobru glasu, jer je bio svojevoljan i nije pazio na redovničku disciplinu. Uživao je i po volji razpolagao sa penzijom od 500. forintih, koju mu je davala 'bosanska vlada'. Radi toga bio je svojevoljan i puno neprilika pravio starješinam provincije, nastojeć samo da ne izgubi milost kod vlade, a za redovničku disciplinu nije puno mario. Imao u samostanu svoju konobu, vino i drugo; bez pitanja gvardijana išao kud je htjeo i kad je htjeo; svak ga se ustručavao, jer je znao i zlonamjerno opanjkati i kod istih svjetovnjaka. Nitko

71 Ljetopis Franjevačkog samostana Kreševo, 3, str. 120.

72 Kronoložke bilješke o. fra Angjela Šunjića od g. 1864.-1888., Studeni misec. 1876. Numan Muminović je u rujnu 1878. bio jedan od glavnih u pokušaju dizanja pobune protiv novouspostavljene austrougarske vlasti pa je, zajedno s nekoliko drugih kreševskih muslimana, uhićen. Ljetopis Franjevačkog samostana Kreševo, 3, str. 166.

73 Ljetopis Franjevačkog samostana Kreševo, 3, str. 125.

74 Isto, str. 227-231. 
Milo Jukić - Fra Grgo Martić kao posrednik...

mu nije mogao ugoditi, nego tko bi htjeo s njim u jednu tikvu, što no reći, puhati. Ovomu manastiru više je svuda škodio nego koristio, jer je bio osvetljiv, ako mu koji gvardijan nije htjeo sekundirati. Novac je trošio po volji, a opet zahtjevao, da mu svaki gvardijan ugadja jelom i pilom. Od dvadeset i više godina, kako je iz Sarajeva došao u manastir bio je najnesnosniji. Prijateljevao sa svjetovnjacima i tražio da ga slave i hvale; darivao druge i rotio ih proti ovomu samostanu, al ipak ga nitko nije htjeo imati, da s njim žive. Hvalilo ga i slavilo na račun sjeromašne ove obćine. Isti mu zemljaci - (Hercegovci, kojim je često zalazio i novcem pomagao) rekli bi: 'S fra Grgom je liepo se razgovarati, al s njim živiti dugo skupa nipošto'. Bio lovac, te mu to bila najmilija zabava. Išao po lovu i u planine, te bio i po više dana. Dok je god mogao - do 2. godine pred smrt - išao je u lov gdje bi na svoj trošak častio družtvo. Pred jesen - i u ljetu - išao bi prijateljima u Djakovo i Hercegovinu na koji mjesec; hodao po toplicam i galantirao, da je svak govorio: 'fra Grgo kako nisko teferiči (zabavlja se). $\mathrm{U}$ to nije žalio trošiti. Kad se ovaj samostan novi gradio, najmanje je doprinio, al ipak odabrao si dvije sobe za sebe. Davao je radije po Hercegovini u gradnje i drugdje nego ovdje gdje je dužan bio."

Kroničar dalje navodi kako je sam sebi za života dao izraditi nadgrobni spomenik te da je novac za postavljenje dao "jednom svjetovnjaku u Kreševu", dodajući da je bio "...dosjetljiv i šaljivdžija, nu nije zazirao od psovke, navlastito kad je koga ružio. Drago mu je bilo izpitivati za sve i privatne mane tudje."

Neki podatci ne uklapaju se u ljetopiščevo mišljenje o fra Grgi. Primjerice, kad je na Badnjak 1868. godine izgorjela samostanska štala, a samostan pretrpio golemu materijalnu štetu, novac za izgradnju nove sakupljan je po svim samostanskim župama i od mnogih pojedinaca. Na popisu donatora našli su se, među ostalim, i francuski konzul te splitski poduzetnici Franjo Moise i Franjo Linardov (poznati kao graditelji sarajevskoga Konaka), a molbenica je poslana i kaločkom nadbiskupu Lajosu Haynaldu, ali je daleko najviše, izuzev Haynalda, odnosno kaločke nadbiskupije, više nego čitava sela i župe (188 groša), dao fra Grgo Martić. ${ }^{75}$

Javno je fra Grgo slavljen i poštovan od svih pa ga je, primjerice, 1902. godine, u povodu 80. rođendana, grad Kreševo pozdravio baklja-

75 Kronoložke bilješke o. fra Angjela Šunjića od g. 1864.-1888., Ožujak misec. 1870. 
dom, gvardijan mu priredio banket, a Hrvatska čitaonica u Kreševu upriličila svečanu akademiju na kojoj je govorio dr. fra Danijel Ban. ${ }^{76}$ Tako je bilo i godinama kasnije, što odlično ilustrira opis obilježavanja 25 godina fra Grgine smrti ${ }^{77}$ te obilježavanje 150 . godišnjice fra Grgina rođenja (1972.), kada je na Filozofskom fakultetu u Sarajevu održan i znanstveni skup o njemu i njegovu djelovanja, a pošta je izdala poseban poštanski žig s njegovim likom. ${ }^{78}$

Razloga za negativno gledanje sigurno je bilo više, a u nekim slučajevima fra Grgo je imao stajališta suprotna samostanskim. Tako je, primjerice, bilo kada je netko od franjevaca napravio u Carigradu dug od 6000 dukata, koji su na kraju morala vratiti sva tri samostana, iako kreševski franjevci s tim nisu imali nikakve veze. Slučaj se prvi put spominje sredinom 1874. godine. ${ }^{79}$

Slično se fra Grgo ponio i u "slučaju Franićević", ${ }^{80}$ kada je kiseljački župnik fra Grgo Franićević pozajmio velik novac za izgradnju župne kuće u Kiseljaku. Zemljište je od nekoga muslimana Trebe kupljeno 1873. godine, a Franićević je u redovitom premještaju poslan na drugu župu, ali je odbio provesti odluku, unatoč očitovanjima provincijala i biskupa, da bi na kraju od biskupa bio "stavljen u prokletstvo". Prije toga je Franićević, uz ostalo, stavljen i u kućni pritvor u samostanu, potom i uhićen (po nalogu fojničkoga kajmakama), ali je u Crnićima pobjegao zaptijama i otišao u Kiseljak. Ispostavilo se da je novac najvjerojatnije potrošen nenamjenski, ali je vraćanje duga određeno kreševskom samostanu, i to ponajviše što je za takvo rješenje, iz kroničarima nejasnih razloga, radio upravo fra Grgo Martić. On je na konačno odlučivanje (u Sutjesci, početkom prosinca 1877. godine) doveo i francuskog konzula. Tada su pale teške riječi, čak i uvrjede, između fra Grge Martića s jedne i kreševskih franjevaca s druge strane. Radilo se o sumi od 150 dukata, koje je samostan na kraju morao isplatiti Franićevićevim povjeriocima, a nakon toga se,

76 Fra Stjepan Buljan, Povijesne crtice Krě̌eva i Franjevačkog samostana 1897.1997., HKD Napredak, Podružnica Kiseljak, 1997., str. 19.

77 Isto, str. 23-24.

78 Isto, str. 35.

79 Ljetopis Franjevačkog samostana Kreševo, 3, str. 87.

80 Isto, str. 128-139, 143-144, 146-149, 151-152. U Kronoložkim bilješkama o. fra Angjela Šunjića od g. 1864.-1888. slučaj se spominje od dijela Godina Gospodinova. 1875. do dijela Misec Veljačah. 1878. O "slučaju Franićević" piše i Baltić (J. BALtić, nav. dj., str. 403). 
Milo Jukić - Fra Grgo Martić kao posrednik...

posredstvom tadašnjega bosanskog biskupa fra Paškala Vujičića, žalio generalu franjevačkoga reda Bernardu a Poru Romatinu u Rimu.

Zanimljivo je da je prije gradnje u samostanu održan sastanak na kojemu je utanačeno da samostan nije dužan davati novac za izgradnju nego "kad župa (Kiseljak) hoće svoj Komod (oli s'godu) neka plati i trošak", ali je sve bilo uzalud. Fra Anđeo Šunjić naziva Martića da je "protector" svog imenjaka Franićevića, a dio duga (30 dukata) odnosio se i na Martića. Martić se i inače, mnogo prije nego je zadobio izdašnu austrougarsku mirovinu, bavio pozajmljivanjem novca pa je u njegovoj ostavštini u kreševskom samostanu sačuvana i njegova knjiga dužnika. ${ }^{81}$

Na prvom sljedećem kapitulu, održanu u Sutjesci, fra Grgo Martić, navodi Šunjić, osvetio se svome kreševskom samostanu, koji je tada, najviše upravo Martićevim i zalaganjem fra Ante Vladića, izgubio dotadašnje pravo na jednoga od definitora Provincije. Oni, tvrdi Šunjić, "...rekli su i pria daće se osvetiti našoj Custodii porad prokletog Franićevića, jerbo su ga oni branili otajno i očito".82 Biskup Paškal Vujičić očito je bio na suprotnoj strani, jer je potvrdio novu tabulu (raspored svećenika po župama) izuzev imenovanja fra Grge Martića za sarajevskoga župnika i fra Ante Vladića u Rami, po Sunjiću, s obrazloženjem "...neka vide tko je starii. Poslie promjene odma počeo Martić u Sarajevu činiti complote, i svoju stranku voditi, te su neki Krstjani pisali Biskupu, da opet ostavi na Župi Martića, tada je njima Biskup odgovorio liepo, da se ne stavljaju u tudje poslove, koga jim starešinstvo dadne Župnika, onoga moraju slušati..." Isti su potom pisali i na druge strane, radeći na tome da fra Grgo ostane sarajevski župnik, među ostalim čak i velikom veziru u Carigrad te austrougarskom ministru vanjskih poslova grofu Gyuli Andrassyju i drugim velikodostojnicima. ${ }^{83}$

\section{Zaključak}

Iako su muslimani i nemuslimani u Osmanskom Carstvu, pa i na području današnje Bosne i Hercegovine, od 1856. godine formalno

81 Dužnici od god. 1850.-1875., Arhiv Franjevačkoga samostana Kreševo, kutija 171/7, Gr. Mar. 43.

82 Kronoložke bilješke o. fra Angjela Šunjića od g. 1864.-1888., Misec Travanj. 1878.

83 Isto. 
imali ista prava, $\mathrm{u}$ stvarnosti su postojale goleme razlike u tretmanu jednih i drugih. Fra Grgo Martić, i kao službeni agent Franjevačke provincije Bosne Srebrene, ali i kao osoba koja je, unatoč nepovoljnoj općoj situaciji, uspjela izgraditi ugled i imati utjecaja na mnoga događanja, nezaobilazan je u rješavanju sporova između katolika te franjevačkih samostana $s$ jedne i osmanske vlasti u Bosni s druge strane. U svemu, osim prilično uskog prostora koji mu ostavljaju zakonske mogućnosti, koristi i dobre odnose s predstavnicima stranih konzulata, a pomaže mu i to što se bori za prava svih potlačenih, bez obzira na konfesionalnu pripadnost.

Djelokrug mu je, kao čelnoj (i praktički jedinoj) osobi Franjevačke agencije, vrlo širok, u opsegu od slučajeva vezanih za pojedince (ubojstvo neimenovanoga muslimana iz Fojnice u Kreševu, ubojstvo neimenovanoga židova iz Sarajeva u Kreševu, ubojstvo Ante Sabljića, nanošenje materijalne štete nekom Tunješu iz Polja od kreševskoga mudira Mehmed-age, ubojstvo Kate Milinušić koje je počinio neki "Sarajlija turčin", itd.) do onih koje opterećuju samostan kao instituciju (zabrana zvonjenja, pokušaj ubojstva lepeničkoga kapelana fra Marka Vilića, pokušaj nezakonite prodaje samostanskoga imanja u Mrakovima kod Konjica, napad Ašima Merdanovića na samostan). Iako se fra Grgino izravno sudjelovanje ne navodi u svakom od spomenutih slučajeva, iz konteksta ukupnih događanja jasno je da ga je uglavnom bilo, a unatoč njegovu očito veliku trudu i zavidnom rasponu metoda djelovanja (članstvo u Medžlisu, dobri odnosi s nositeljima vlasti, privatna poznanstva i veze, sposobnost da za pomoć pridobije strane diplomate), ne uspijeva sve probleme riješiti pozitivno.

Unatoč svemu navedenom te nekim konkretnim pokazateljima koji govore suprotno, fra Grgo, makar se to više odnosi na njegov redovnički život nego na svjetovno djelovanje, nije pozitivno ocijenjen od neke svoje subraće iz kreševskoga samostana, dijelom i zbog toga što je u određenim sporovima stao na stranu onih koji su vodili sporove protiv toga samostana. 


\section{Fra Grgo Martic as the intermediary between Catholic Church and Ottoman authorities in the unpublished chronicles of the Franciscan monastery Kresevo}

\section{Summary}

Almost entire $19^{\text {th }}$ century in Bosnia and Herzegovina, up to the establishment of Austro-Hungarian rule, abounds in turbulence caused by weakening of the Ottoman Empire and aspirations of the European forces of that time to solve the problems caused by such state and events. The Ottoman Government tried to solve problems in different ways, firstly by legal regulations (Edict of Gülhane in 1839, Hatti Humayun of 1856), but the will and strength for their implementation were missing, so the results were almost negligible and position of Catholics and Catholic Church increasingly unenviable.

Fra Grgo Martic, as the agent of Franciscan Province of Bosna Srebrena in Sarajevo, was the intermediary between Ottoman authorities and Franciscan monastery Kresevo.

Working on that plan intensively, as a member of Sarajevo Medzlis (Council), but also privately, within possible and allowed limits, he communicated with representatives of authorities and contacted diplomatic representatives of other countries for help in solving certain disputes and in the situations where they could have certain influence.

Such cases were in details described in the unpublished monastery chronicles written between 1864 and 1878 .

Keywords: Fra Grgo Martic; Franciscan monastery Kresevo; chronicles; vizier; Sarajevo. 